\title{
How Physiotherapeutic and Yogic Interventions can be used for Treatment of Primary Hypertension?
}

\author{
Mayank Shukla* \\ Amity Institute of Physiotherapy, India \\ Submission: June 18, 2018; Published: August 17, 2018 \\ *Corresponding author: Mayank Shukla, Assistant Professor, Amity Institute of Physiotherapy, India, Email: mshukla@amity.edu
}

\section{Introduction}

\section{Hypertension (HTN)}

The leading risk factor for many diseases; has highest prevalence $(\sim 40 \%)$ in low and middle-income countries as per the estimates of world wide data by world health organization (WHO) [1]. It causes significant mortality $-13.5 \%$ of total, [2] via cardio and cerebral injuries. A low cost and sustainable preventive solution, for this can be provided by yoga and physiotherapy. HTN is clinically defined as -increased systolic and diastolic blood pressures, the guidelines for which are ever evolving, albeit $140 / 90 \mathrm{~mm}$ of $\mathrm{Hg}$, staying as a treatment target throughout this evolution [3].

HTN is the body's response to excessive stress - [4] of physical, psychological or pathological nature where the prana vayu (equivalent of disbursed oxygen) is chronically overconsumed by sympathomimetic components - in a chronic hyperactive state of body, mind and it disorients the life-force leading to afflictions of vyan vayu (equivalent of content of oxygen in arterial blood; due to vasoconstriction) in various organ systems [5]. It leads to disturbances of vata, pitta and couf by fluid overload.

Oxygen or Prana vayu delivery to tissues is the prime function, for survival and occupation. This is delivered to different body parts during different states of the bodily requirement and is the fine regulator for many autonomic nervous system parameters. However, contrary to the situation of HTN, in a state of rest, mediation, or during peaceful slumber the sympatholytic components get prana vayu, and there is abundance of vyan vayu in those areas. In HTN to compensate for lack of this, there is increased fluid overload, cardiac hypertrophy and marked reninangiotensin-aldosterone adaptations.

Scientific application of yoga and physiotherapy have credible potential, for the treatment of primary hypertension [6-8]. Patient selection for these interventions shall be based on -uncomplicated cases without target organ damage, and with the ability to perform the practices of yoga and physiotherapy in asymptomatic manner.
The contraindications like retinopathy, nephropathy or significant cardiac abnormalities shall be ruled out.

Yogic practices like Shavasna, Anulomvilom pranayama, meditation with Om chanting and physiotherapy exercises like hold relax, Jacobson's relaxation, deep diaphragmatic breathing tune the autonomic control towards parasympathetic tone in general and decrease blood pressure noticeably [6]. As per the specificity, principle of yoga \& exercise training the adaptations of the cardiovascular system will be conditioned responses, that is the fine tuning of the reflex mechanism (autonomic modulation= heart rate variability (HRV) and baroreflex sensitivity (BS) as well as the hemodynamics of the cardiovascular system [9]. No activity / active rest, profound relaxation and psycho-physiological adaptability to stress is undoubtedly the key for its treatment. Low level of exercise (or the type that we use for physical activities) is shown to have no effect on arterial compliance, and by inducing increased flow it can have a greater increase in nitric oxide availability, tuning BS and SD improvements of HRV, which may explain post exercise hypotensive response [10]. This type of training may have a potential effect on the pathogenesis, as well as on the treatment of hypertension. In people with mild to moderate high blood pressure, studies have demonstrated that regular aerobic activity can decrease blood pressure by up to 10/8mm Hg [11].

Moreover, mild to moderate exercises are reported to suppress platelet adhesiveness and aggregation, whereas heavy exercises induce a transient increase in agonist-induced platelet aggregation, as well as increased platelet counts, adhesiveness and secretary activity. These effects seem to be more pronounced in sedentary than active healthy subjects, thus potentially explaining the risk of sudden death in susceptible sedentary individuals or in patients with pre-existing atherosclerotic vascular disease [12]. Certain yogic asanas like Halasan, Sarvangasna and Shirhsaasna divert the blood towards the central sinuses, it fine tunes the BS. Physiotherapeutic tilt table exercises and gravity assisted positions also perform the same function [6]. Suspension bed and 
tilt table can be effectively used for this purpose. The re-setting of baroreflex is a new non-pharmacological intervention for the hypertension [6].

Suryanamaskar gives the prana vayu with pranic force of sunlight (related to vitamin D, nitric oxide and vagal predominance) with increased elasticity and flexibility, controlled breathing in the ample sunlight'; similar benefits can be gained by artificial actinotherapy sources and passive stretching and breathing exercises. TL01 has been shown to be effective in reduction of $\mathrm{BP}$, and improvement of vitamin D levels [13]. Sunlight but not vitamin D spectrum metabolites are known to have a vasoprotective effect on the blood pressure indices [14]. However, the unique combination only exists in the practice of Suryanamaskar, which helps to regulate and optimize the lifeforce - reflected in a decreased resting metabolic rate and higher $\mathrm{VO}_{2} \max [15]$.

\section{Mechanism of antihypertensive effect of yoga and physiotherapy-}

A. Increased endothelium dependent vasodilatation through increased production of Nitric oxide [8]

B. Reduced sympathetic nervous activity [16]

C. $\quad$ Reduced arterial stiffness [17]

D. Increased insulin sensitivity [18]

E. Reduced lipid levels, abdominal fat independent of weight loss $[19,20]$

F. Increased exercise capacity there by reducing symptoms at same workloads.

$\left(\mathrm{VO}_{2} \mathrm{max}=\mathrm{CO} \times \mathrm{CaO}_{2}-\mathrm{CvO}_{2}\right.$ Increased capillarization may lead to increased $\mathrm{VO}_{2}$ max at same $\mathrm{CO}$ ) $\mathrm{VO}_{2}$ max= maximum oxygen uptake; $\mathrm{CO}=$ cardiac output; $\mathrm{CaO}_{2} / \mathrm{CvO}_{2}=$ content of oxygen in arterial or venous blood [21]. At present it is difficult to pinpoint the specific yogic kriya or asana or physiotherapy intervention to the specific mechanisms listed above [7]. To ensure safety monitoring of the following parameters shall be undertaken routinely-
1. Pulse/HR
2. $\mathrm{SBP}, \mathrm{DBP}$
3. $\mathrm{SaO}_{2}$
4. ECG (resting)
5. Borg's Scale of perceived exertion.
6. Aerobic fitness, 6 MWTD

Decrease in blood pressure, by short duration regular yogic practices is known to slow down and reverse the cognitive decline and improve mental function and quality of life [2225]. Once BP starts to come back to lower and normal levels the antihypertensive medications shall be readjusted with the consultation of the experts.

\section{References}

1. WHO (2013) A global brief on hypertension. Silent killer, Global public health crisis.

2. Arima H, Barzi F, Chalmers J (2011) Mortality patterns in hypertension. J Hypertens 29(Suppl 1): S3-S7.

3. Mancia G (2014) Hypertension: strengths and limitations of the JNC 8 hypertension guidelines. Nat Rev Cardiol 11(4): 189-190.

4. Panjwani U, Singh SB, Harinath K, Yadav DK, Selvamurthy W (1999) Effect of stress on somatosensory evoked potentials. Stress medicine 15(1): 35-40.

5. Avhad AD (2013) Understanding essential hypertension through Ayurveda a review. International Journal of Pharmaceutical \& Biological Archive 4(4).

6. Selvamurthy W, Sridharan K, Ray US, Tiwary RS, Hegde KS, et al. (1998) A new physiological approach to control essential hypertension. Indian J Physiol Pharmacol 42(2): 205-213.

7. Ross A, Thomas S (2010) The health benefits of yoga and exercise: a review of comparison studies. J Altern Complement Med 16(1): 3-12.

8. Goto C, Higashi Y, Kimura M, Noma K, Hara K, et al. (2003) Effect of different intensities of exercise on endothelium-dependent vasodilation in humans: role of endothelium-dependent nitric oxide and oxidative stress. Circulation 108(5): 530-535.

9. Chobanian AV, Bakris GL, Black HR, Cushman WC, Green LA, et al. (2003) The seventh report of the joint national committee on prevention, detection, evaluation, and treatment of high blood pressure: the JNC 7 report. JAMA 289(19): 2560-2571.

10. MacDonald JR (2002) Potential causes, mechanisms, and implications of post exercise hypotension. J Hum Hypertens 16(4): 225-236.

11. Sales MM, de Sousa CV, de Paula Santana HA, Motta Santos D, Barbosa LP, et al. (2018) Nitric oxide and blood pressure responses to shortterm resistance training in adults with and without type-2 diabetes: a randomized controlled trial. Sport Sciences for Health, pp. 1-10.

12. Wang JS, Jen CJ, Kung HC, Lin LJ, Hsiue TR, et al. (1994) Different effects of strenuous exercise and moderate exercise on platelet function in men. Circulation 90(6): 2877-2885.

13. Shukla M, Shenoy S, Singh A, Sandhu JS, Vishwakarma G (2016) Narrowband TL01 for the treatment of vitamin D deficiency in individuals of Fitzpatrick skin type IV \& V. Indian Journal of Basic and Applied Medical Research 5(2): 537-544.

14. Geleijnse JM (2011) Vitamin D and the Prevention of Hypertension and Cardiovascular Diseases: A Review of the Current Evidence. Am J Hypertens 24(3): 253-262.

15. Bhutkar PM, Bhutkar MV, Taware GB, Doijad V, Doddamani BR (2008) Effect of Suryanamaskar practice on cardio-resperatory fitness parameters. A Pilot Study. Al Ameen J Med Sci 1(2): 126-129.

16. Brown RP, Gerbarg PL (2005) Sudarshan Kriya yogic breathing in the treatment of stress, anxiety, and depression: part I-neurophysiologic model. J Altern Complement Med 11(1): 189-201.

17. Kim S, Bemben MG, Bemben DA (2012) Effects of an 8-month yoga intervention on arterial compliance and muscle strength in premenopausal women. J Sports Sci Med 11(2): 322-330.

18. Innes KE, Vincent HK (2007) The influence of yoga-based programs on risk profiles in adults with type 2 diabetes mellitus: a systematic review. Evid Based Complement Alternat Med 4(4): 469-486.

19. Wong SL, Katzmarzyk PT, Nichaman MZ, Church TS, Blair SN, et al. (2004) Cardiorespiratory fitness is associated with lower abdominal fat independent of body mass index. Med Sci Sports Exerc 36(2): 286291. 
20. Mahesh NK, Kumar A, Bhat KG, Verma N (2018) Role of yoga therapy on lipid profile in patients of hypertension and prehypertension. International Journal of Advances in Medicine 5(2): 321-326.

21. Rowland TW (2005) Circulatory responses to exercise: are we misreading fick? Chest 127(3): 1023-1030.

22. Metri KG, Pradhan B, Nagendra HR (2017) Impact of short-term residential yoga-based lifestyle intervention on Cognitive function in hypertensive patients. Journal of Stem Cells 12(1): 33.

23. Oken BS, Zajdel D, Kishiyama S, Flegal K, Dehen C, et al. (2006) Randomized, controlled, six-month trial of yoga in healthy seniors:

This work is licensed under Creative

Commons Attribution 4.0 License

DOI: 10.19080/JYP.2018.05.555672 effects on cognition and quality of life. Altern Ther Health Med 12(1): 40.

24. Ray US, Mukhopadhyaya S, Purkayastha SS, Asnani V, Tomer OS, et al. (2001) Effect of yogic exercises on physical and mental health of young fellowship course trainees. Indian J Physiol Pharmacol 45(1): 37-53.

25. Hariprasad VR, Koparde V, Sivakumar PT, Varambally S, Thirthalli J, et al. (2013) Randomized clinical trial of yoga-based intervention in residents from elderly homes: Effects on cognitive function. Indian J Psychiatry 55(3): S357-S363.

\section{Your next submission with Juniper Publishers will reach you the below assets}

- Quality Editorial service

- Swift Peer Review

- Reprints availability

- E-prints Service

- Manuscript Podcast for convenient understanding

- Global attainment for your research

- Manuscript accessibility in different formats

(Pdf, E-pub, Full Text, Audio)

- Unceasing customer service

Track the below URL for one-step submission

https://juniperpublishers.com/online-submission.php 